\title{
The Rhetoric of Appropriation and Dissociation in Evodius' Aduersus Manichaeos: A Case Study of Anti-Manichaean Polemics
}

\author{
Aäron Vanspauwen
}

\section{Introduction}

The present contribution centres on an anti-Manichaean treatise attributed to Evodius of Uzalis, who was a friend of Augustine of Hippo. ${ }^{1}$ The treatise is known under the title De fide contra Manichaeos, although the title Aduersus Manichaeos would be more historically accurate. ${ }^{2}$ Evodius was appointed bishop of the North African colonia Uzalis (present-day El Alia, Tunisia) at the end of the fourth century, and wrote the treatise, presumably, around $420-425 \cdot{ }^{3}$ The aim of the treatise Aduersus Manichaeos is to refute the Manichaeans and their claim to a Christian identity on biblical-doctrinal grounds

1 This paper presents an adapted version of my lecture for the international meeting "Religious Polemics and Encounters in Late Antiquity." Its contents coincide with sections from the fourth chapter of my doctoral dissertation "In Defence of Faith, Against the Manichaeans: Critical Edition and Historical, Literary and Theological Study of the Treatise Aduersus Manichaeos, Attributed to Evodius of Uzalis" (Ph.D. diss., KU Leuven, 2019). The fourth chapter of this dissertation studies the content and language of Aduersus Manichaeos. For references to the text of Aduersus Manichaeos, I will make use of the following edition: Aäron Vanspauwen, "The anti-Manichaean Treatise De fide contra Manichaeos, Attributed to Evodius of Uzalis: Critical Edition and Translation," Sacris Erudiri 57 (2018): 7-116. The numerical references in this paper indicate the chapter and line numbers of this edition. English translations of Aduersus Manichaeos are mine, and can be found in the same article. A previous edition of Aduersus Manichaeos can be found in Josephus Zycha, Sancti Aureli Augustini contra Felicem, de natura boni, epistula Secundini, contra Secundinum, accedunt Euodii de fide contra Manichaeos et commonitorium Augustini quod fertur (CSEL 25/2; Prague: Tempsky, 1892), 951-975.

2 On this topic, see François Decret, "Le traité d'Evodius contre les Manichéens: Un compendium à l'usage du parfait controversiste," Augustinianum 31 (1991): 387-409; Aäron Vanspauwen, “'Contra Domini uel Apostoli auctoritatem': La autoridad de Pablo en el tratado Polémico 'De fide contra Manichaeos' de Evodio de Uzala," Augustinus 61 (2016), 397-398.

3 See Vanspauwen, "In Defence of Faith," 94-95. This hypothesis presumes that Evodius wrote the treatise after consultation of Augustine's Contra aduersarium legis et prophetarum (419420), and before Evodius wrote his Epistula ad Valentinum (425-426). On this letter, see YvesMarie Duval, "Note sur la lettre d'Evodius à l' abbé Valentin d'Hadrumète (CPL 389)," REAug 49 (2003): 123-130. 
and, as such, Evodius attempts to convert the addressed Manichaeans to Catholic Christianity.

This paper will address the theme of "religious polemics and encounters" in four regards. First, it deals with polemical relations between Manichaeans and mainstream Christians in North Africa. The author of Aduersus Manichaeos, Evodius, addresses the Manichaeans in an appeal to conversion. Second, his rhetorical language frames his opponents, the "other," in a multifaceted manner. While many of the descriptions of his opponents (or addressees) are rather slanderous, some of these characterisations also serve the overarching argumentative purpose of the treatise. Third, this paper considers the degrees and variations of this polemical encounter, specifically addressing the following question: Is Evodius' appeal towards the Manichaeans only effective as an argumentative tool, or does his treatise constitute a genuine invitation to Catholic Christianity? Fourth, and finally, these aforementioned topics are integrated in the specific focus of this paper on the polemical/rhetorical strategies of the treatise Aduersus Manichaeos.

\section{Preliminary Discussions}

\subsection{The Manichaean-Catholic Debate}

In Roman North Africa, different religious movements claimed a Christian identity. The Manichaeans considered themselves Christians, and the Catholic polemicists also addressed the Manichaeans as Christians. ${ }^{4}$ In contrast to the mainstream (or non-Gnostic) Christian churches, such as the Donatists, Catholics, and Arians, the Manichaeans adhered to a dualistic view of reality. The cosmos consists of two natures or kingdoms: The kingdom of light and the kingdom of darkness. God rules over the kingdom of light, whereas the kingdom of darkness is subject to the prince of darkness. In Manichaean cosmology, all elements of the kingdom of light are of equal substance; or, to phrase it differently, the entire kingdom of light consists of emanations of God, the pure light. The dualism of good and evil served to explain the existence and origin

4 See Johannes van Oort, "Manichaean Christians in Augustine's Life and Works," Church History and Religious Culture 9o (2010), 507-509; Adu. Man. 39, 19-22: Tandem uigilate et blasphemiis conquiescite atque omnium sanctarum canonicarum Scripturarum, si Christiani esse cogitatis, auctoritatem recipite et quae non intelligitis accusare nolite, sed potius eorum intellectum desiderate: "At last, be vigilant, cease your blasphemous teachings, and if you think you are Christians, accept the authority of all holy and canonical Books. Stop blaming what you do not understand, but rather desire the understanding of those passages". 
of evil, and guided Manichaean ethics. The present experience of evil results from the cosmic conflict between light and darkness. The Manichaean doctrine can, therefore, be described as a doctrine of two natures (light-darkness) and three times (beginning-middle-end, or protology, present, and eschatology). ${ }^{5}$ The two primordial elements of light and darkness were strictly separated at the beginning and will be separated again at the end of times. In the present age (the second or middle period), however, the two elements have become intermingled. A human person reflects, on a microcosmic level, the macrocosmic conflict between light and darkness. Because darkness signifies death and lust, Manichaeans radically adhered to the principle of nonviolence, to the extent that the Manichaean Elect would not harm fruit or vegetables. In general, the Manichaeans strongly condemned sexual concupiscence and the begetting of children. ${ }^{6}$

Non-Manichaean or non-Gnostic Christianity, on the other hand, held that there could be only one principal cause behind reality: God. God is the cause and creator of all reality. Nothing can be on the same ontological level as God and, thereferore, evil cannot be a nature inherent to, or preceding, creation. Catholic polemicists, in their disputes with the Manichaeans, propounded that evil was not a constitutive element of reality, but rather, in some sense, something which resulted from the imperfection of created existence. Augustine and Evodius, for instance, argue that evil and sin are moral rather than ontological realities.

\subsubsection{Evil Is Not a Nature}

In general, Evodius was strongly influenced by Augustine's criticism of the Manichaeans. Augustine found that the Manichaean dualism was not a real dualism, that is, a dualism between two equivalent elements. On the contrary, he claims, darkness does not exist in and of itself, but is merely the absence of light. Where there is light, there cannot be darkness. Darkness only appears to exist where there is no light. Augustine criticises the Manichaeans' materialistic conceptualisation of God arising from their materialistic images of the two kingdoms. ${ }^{7}$ He accuses the Manichaean conceptualisation of God of being

5 See, for example, Iain Gardner and Samuel Lieu, Manichaean Texts from the Roman Empire (Cambridge: Cambridge University Press, 2004), 11;Jean-Daniel Dubois, "Le manichéisme: à la lumière des documents nouveaux," in Contre Fauste le manichéen: Livres I-XII (ed. M. Dulaey; BA 18/A; Paris: Institut d'Études Augustiniennes, 2018), 53-56.

6 On Manichaean ethics, see, for example Michel Tardieu, Le manichéisme (Que sais-je? 1940; Paris: PUF, 1981), 79-89; Gardner and Lieu, Manichaean Texts, 21-25.

7 Aug. c. ep. fund. 21 (CSEL 25/1, 218) Quid erat ergo iuxta illud latus terrae, quam inlustrem ac 
"corporeal" (carnalis). ${ }^{8}$ This judgement of Augustine is probably correct. The Manichaean dualism is not a dualism that distinguishes precisely between a spiritual good and a corporeal evil, because light is also defined in quantifiable and spatial terms and has corporeal characteristics. ${ }^{9}$

In response to Manichaean dualism, Augustine formulated his views on creation which place God at the centre of creation. Since Augustine could not accept that God created us from pre-existent matter, he formulated the doctrine of creation de nihilo (from nothing). Creation is created by God (ex Deo), yet draws its substance from nothing (de nihilo). Because God created us from nothing, there is no source of stability and identity for human existence other than God. Human nature at its very core, thus, is relational and connected to God. ${ }^{10}$ In other words, the created human nature is good because it is caused by, or created by, a good God, yet nonetheless imperfect because it draws its substance from nothing.

Augustine makes use of the Manichaean image of light and darkness in his refutation of their dualistic views. Darkness is not the opposite of light, but the absence of light. Because darkness is present where there is no light, darkness is also part of God's orderly creation. ${ }^{11}$ Making use of another metaphor, Augustine explains how silence does not exist as the opposite of sound, but is found only in the absence of sound. These images illustrate Augustine's conception of evil not as a substance which is the opposite of good, as the Manichaeans

sanctam uocas? terra, inquit, tenebrarum. quid? de ista terra saltem concedis, quod corporea erat. necesse est te hoc dicere, quandoquidem omnia corpora inde adseris originem ducere. quid ergo? quaeso, quamuis tardi, quamuis carnales homines, ne hoc quidem aliquando animaduertitis, quod lateribus sibi iungi utraque ista terra non posset, nisi esset utraque corpore?: "But what, then, was next to the side of the land that you call bright and holy? Mani says that it was the 'land of darkness.' What is that? You at least concede that that land is bodily. You must say this since you say that all bodies derive their origin from it. What follows then? Though you are slow, though you are carnal human beings, I ask, 'Do you not at last see that these two lands could not touch each other by their sides if both were not bodily?' " (trans. R. Teske, The Manichaean Debate [WSA I/19; New York: New City Press, 20o6], 248-249).

8 Aug. c. ep. fund. 23 (CSEL 25/1, 220) ecce, ego tecum derideo carnales homines, qui nondum possunt spiritalia cogitare humana forma deum existimantes; Aug. c. Sec. 20 (CSEL 25/2, 938) carnalis uestra cogitatio.

9 See the introduction of Gardner and Lieu, Manichaean Texts, esp. 11 and 22-23.

10 See Matthew Drever, "Redeeming Creation: Creatio ex nihilo and the Imago Dei in Augustine," International Journal of Systematic Theology 15 (2013), 141.

11 Aug. nat. bon. 16 (CSEL 25/2, 861) nam et deus certa loca et tempora non inluminando tenebras fecit tam decenter quam dies: "For, by not giving light to certain places and times, God also made darkness just as appropriately as daylight" (trans. Teske, The Manichaean Debate, 328-329). 
believed, but rather as a privation or diminishment of good. This is the socalled doctrine of priuatio boni. Evil, understood as a privation of good, is thus part of God's orderly creation, though not created as such by God. ${ }^{12}$ In other anti-Manichaean texts, Augustine says that "natural evil" does not exist as a substance, and argues that when we speak of "natural evil," two forms of evil are being described: Sin (peccatum) and the punishment of $\sin ($ poena $) \cdot{ }^{13}$ Humans sin by using their free will; God, as a righteous judge, punishes sin. God created the world as orderly, and by punishing sin, he restores order in creation.

Evodius generally follows Augustine's argumentation against the Manichaeans. Like Augustine, he maintains that evil cannot be a substance, and thus does not believe that Manichaean dualism is a real dualism. ${ }^{14}$ Natural evil does not exist. Similarly to what Augustine stated, evil only exists in the form of sin and punishment:

But even if we say some people are naturally evil, we say so because of the origin of the ancient sin, in which, at present, our mortality is born. And so, everything that is called evil in humans, is sin and punishment. A sin is committed through the rational soul, which possesses a free judgment of will, and the punishment is inflicted on behalf of God's justice, which by no means acts unjustly. ${ }^{15}$

12 Aug. nat. bon. 16 (CSEL 25/2, 861) si enim nos continendo uocem decenter interponimus in loquendo silentium: quanto magis ille quarundam rerum priuationes decenter facit sicut rerum omnium perfectus artifex? "After all, if by holding back our voice we fittingly inject a silence in our speaking, how much more did he as the perfect artisan of all things fittingly produce privations of certain things?"; (trans. Teske, The Manichaean Debate, 329); Augustine already formulated his doctrine of evil as the privation of good in his earliest anti-Manichaean texts mor. See Aug. mor. Man. 4, 6 (CSEL 90, 92) Ita et malum ostenditur quomodo dicatur, non enim secundum essentiam, sed secundum priuationem uerissime dicitur: "In that way we are shown how evil is spoken of, for it is most truly spoken of not as an essence but as a privation" (trans. Teske, The Manichaean Debate, 71).

13 Aug. c. Fort. 15 (CSEL 25/1, 91) et hoc est solum, quod dicitur malum, uoluntarium nostrum peccatum. est et aliud genus mali, quod est poena peccati: "And this is the only thing that we are at present calling evil: our voluntary sin. But there is another kind of evil, which is the punishment of sin"; (trans. Teske, The Manichaean Debate, 150); Aug. c. Adim. 26 (CSEL 25/1, 184) dupliciter enim appellatur malum: unum quod homo facit, alterum quod patitur; quod facit, peccatum est; quod patitur, poena: "For we speak of two kinds of evil: one that human beings do, another that they suffer. The evil that they do is sin; the evil that they suffer is punishment" (trans. Teske, The Manichaean Debate, 219).

14 Adu. Man. 9, 2-3: malum enim non potest esse natura nec substantia nec uita; "for evil can be neither a nature nor a substance nor a life".

15 Adu. Man. 9, 4-8: Sed et si aliquos naturaliter dicimus malos, propter originem ueteris peccatis dicimus, in quo iam nostra mortalitas nascitur. Totum itaque quod uocatur malum in 


\subsubsection{Dualism as an Argumentative Premise}

Although Evodius agrees with Augustine that evil cannot be a nature, he nevertheless often refutes the Manichaean dualism as if it is a true dualism. Evodius does not reject Manichaean dualism a priori. Instead, he first accepts, as an argumentative premise, the possibility of a dualistic reality. He subsequently explores the implications of this dualism before refuting it outright. ${ }^{16}$ For example, when he discusses the primordial distinction between God and the Manichaean prince of darkness, he claims that these two cannot be true opposites since they both share the same attributes in the Manichaean system, such as an eternal existence. ${ }^{17}$ In a later section, he also explores whether or not Manichaean dualism can offer a satisfactory response to the question of human accountability for $\sin .{ }^{18}$ Thus, when refuting Manichaean dualism, Evodius takes the dualism seriously, even if he does not agree with the premise that there actually are two natures. It is possible he thought that, by first presenting dualism as a theoretical possibility, he could later reject Manichaean dualism more convincingly. The author first searches for a common ground between the Manichaeans and the Catholics before refuting the Manichaean position. This means of argumentation also becomes clear in his use of biblical passages, particularly in his recourse to the testimony of the apostle Paul. ${ }^{19}$

hominibus, peccatum est et poena. Peccatum fit ab anima rationali, cui liberum uoluntatis arbitrium est, en poena infligitur iustitia Dei, quae nihil facit iniuste.

16 Such an argumentative procedure was common in Late Antiquity. See, for example, the discussion of immanent critique in Augustine's De ciuitate dei in Gerald P. Boersma, "Augustine's Immanent Critique of Stoicism," SJT 70 (2017): 184-197.

17 Adu. Man. 3, 5-8: Et si contrarium est bonum malo, ex aliqua ergo parte discordabit bonum a malo; ex multa uero coniunctum et concordans erit et non iam erit merum malum habendo tanta communia bona cum Deo: "And if good is contrary to evil, in some regard it will be in disagreement with evil. However, for the most part it is in accordance and in agreement with it. And evil will not be pure evil, because it has so many good attributes in common with God".

18 Adu. Man. 43, 7-10: Necesse est ergo ut aut pars lucis peccet aut pars tenebrarum. Sed si pars lucis peccat, Deus peccat, quod nefas est dicere. Si autem pars tenebrarum peccat, ipsa uocatur ad regnum per eum qui dixit: Non ueni uocare iustos, sed peccatores, quia non est opus sanis medicus, sed male habentibus: "It is thus necessary that either the part of light sins, or the part of darkness. But, if the part of light sins, God sins, which is a wicked thing to say! If, then, the part of darkness sins, this part will be summoned to the kingdom by him who said: I have come not to call the righteous but sinners, for those who are well have no need of a physician, but those who are sick do" (Matt 9:13-12 [sic]).

19 See on this topic also Vanspauwen, “'Contra Domini uel Apostoli auctoritatem.'” 


\subsection{Addressees of the Treatise}

In one of his discussions on Adu. Man., the scholar François Decret noted that the argumentation of the treatise would probably not have convinced many Manichaeans. ${ }^{20}$ As a compendium of anti-Manichaean argumentation, it was perhaps written, in the first place, to a favourable audience of fellow Catholic Christians. Indeed, on several occasions, Evodius seems to address a Christian audience and refers to the Manichaeans as a third party. ${ }^{21}$ Nevertheless, in most cases, verbs in the second person plural (the second person singular is rare) refer unambiguously to the Manichaeans. At least formally, the Manichaeans are the addressees in the treatise. It is very telling that, in contrast to Augustine before him and Quodvultdeus after him, Evodius never addresses his adversaries as "heretics." The treatise's ultimate goal is to convince the addressees to convert to the Catholic Church, and this invitation seems sincere.

When the author refers to Manichaeans in the third person, he often uses the pronoun iste. This pronoun can have a negative connotation, possibly in ista impietate Manichaei ("that [vile] impiety of Mani"). ${ }^{22}$ However, in the first place this demonstrative pronoun functions as situating individuals or objects as near to the second person or the addressees. When the author uses the pronoun iste to refer to the Manichaeans in the third person, this usage of the pronoun could, thus, be interpreted in two ways. Firstly, Evodius could simply be speaking to a Catholic audience. By referring to the Manichaeans as isti, he pictures the Manichaeans as present near his Christian audience ("the Manichaeans whom I am talking about in this conversation with you"), while perhaps not eschewing the pronoun for its (secondary) pejorative connotations ("those malicious Manichaeans"). Secondly, and alternatively, he indeed

20 François Decret, "Exégèse et polémique chez Evodius d'Uzalis," in L'Esegesi dei padri latini: dalle origini a Gregorio Magno (Studia Ephemeridis Augustinianum 68, vol. 1: Parte Generale-Oriente, Africa; Rome: Institutum Patristicum Augustinianum, 2000), 383389 .

21 See, for example, Adu. Man. 31, 8-9: et tamen quis ferat tam incredibiles blasphemias quas isti de ipsa passione Domini proferre non dubitant?: "And still, who could bear this incredible blasphemy which they do not hesitate to profess concerning the Lord's Passion?". See also the discussion on the genre of "protreptic" (polemical text, directed against adversaries) and "paraenetic" (encouragement to fellow believers) in Annemaré Kotzé, "Protreptic, Paraenetic and Augustine's Confessions," in 'In Search of Truth:' Augustine, Manichaeism and other Gnosticism (ed. J.A. van den Berg et al.; Nag Hammadi and Manichaean Studies 74; Leiden and Boston: Brill, 2011), 3-23. Kotzé rightly argues that one should not see too sharp a distinction between the protreptic and paraenetic approaches, in that one work can be intended to be read by 'insiders' and 'outsiders' alike. The paper presented here focusses on the protreptic aspects of Aduersus Manichaeos. 
intends to address an audience of Manichaeans, and his use of iste is an intentional attempt to divide the Manichaeans into two parties, distinguishing between those addressees who are receptive to his message, and those who would remain believers of Mani's teachings.

One example might illustrate these alternative interpretations: Quis tam caecus est, ut ista credat, rogo uos?23 In this quotation, Evodius directly addresses his audience in the second person plural (uos), and underlines the urgency of his message by using the lively phrase rogo uos (which, in itself, contains a rare use of the first person). If he is addressing a Catholic audience here, he obviously expects his audience to express its dissatisfaction with the concerning Manichaean doctrine. The demonstrative pronoun ista refers to the Manichaean teachings, and has the connotation of "these teachings I present to you." The pronoun may also have carried a negative undertone in this case. Alternatively, if addressing the Manichaeans, his statement is an appeal to conversion carried out in an affected rhetorical tone. In his phrasing, he created distance between the addressed Manichaeans, whom he wants to convert to Catholic Christianity, and the Manichaean myth. These teachings are characterised as being present near the second person (ista: "what those among you believe") and, thus, the author exhorts the Manichaeans to reject Mani's teachings. In both cases, whoever continued to believe the Manichaean myth is then described as caecus ("blind").

Evodius, through his refutation of Manichaeism (or the Manichaean interpretations of the Christian tradition), attempts to convert his addressed Manichaeans to the Catholic Church. The envisaged conversion pertains exclusively to matters of intellect and doctrine. He asks his addressees to pursue truth as taught by the Catholic Church. In order to achieve this purpose, Evodius makes use of the argumentative strategies of appropriation and dissociation. By "appropriation," I mean that Evodius makes use of the Manichaean distinction between light and darkness in order to demonstrate that his views correspond to light and those of Manichaeism correspond to darkness. The term "dissociation" refers to the distinction Evodius makes between his addressed Manichaeans and Mani, the founder of the Manichaean myth. By creating a gap

23 Adu. Man. 17, 15-16: "Who is blind to such an extent that he would believe those words, I ask you?" 
between Mani and the Manichaeans, he attempts to win over his addressees. As will be demonstrated in what follows, Evodius characterizes Mani as a misleading teacher, and thereby concludes that the Manichaeans are being misguided. At the same time, Evodius establishes that the Manichaeans could still achieve salvation. If they are of good will, they should accept Evodius' invitation and convert to Catholic Christianity.

\subsection{The Language of Light and Darkness}

The images of light and darkness play a fundamental role in Manichaean cosmogony and ethics. As stated above, the Manichaeans distinguished between two kingdoms: the kingdom of light and the kingdom of darkness. In Adu. Man., a wide array of terms is used to speak of light, darkness, and associated concepts. For the concept of light, these terms are accendo ("to light"), (prae)clarus ("bright, shining"), declaro ("to reveal"), ignis ("fire"), igneus ("fiery"), lucidus ("full of light, clear"), lumen ("light"), lux ("light"), radius ("ray [of the sun]"), reuelo ("to reveal"), and sol ("the sun"). Terms associated with darkness are caecitas ("blindness"), caecus ("blind"), excaeco ("to blind"), nebula ("cloud"), nox ("night"), tenebrae ("darkness"), uelum ("veil").

Some of these terms have their origins in Manichaean sources. Indeed, the citations of Manichaean texts in Adu. Man. contain many references to light and darkness. Evidently, light is always portrayed as good, and darkness as evil, or as a danger which must be overcome. The Manichaean texts employ the adjectives clarus (twice as the superlative clarissima, in conjunction with nauis ${ }^{24}$ ), praeclarus (describing a Manichaean deity ${ }^{25}$ ), and lucidus (once in conjunction with natura, describing the original good origin of the soul; ${ }^{26}$ three times in conjunction with naues $;{ }^{27}$ once in conjunction with uirginum; ${ }^{28}$ Evodius' reference to the lucidum tectorium also seems to reflect an

24 Adu. Man. 14, 6 in clarissima hac naui; Adu. Man. 16, 3-4 ex ista magna et clarissima naui. Cf. Mani's Thesaurus (ed. M. Stein, Manichaica latina 4: Manichaei Thesaurus; Papyrologica Coloniensia 27/4; Paderborn: Schöningh, 2016), 38, 1. 4-5; 42, 1. 3 o.

25 Adu. Man. 11, 6-7 nisi aliquod eximium ac praeclarum et uirtute potens opponat. Cf. Mani's Epistula fundamenti (ed. M. Stein, Manichaica latina 2: Manichaei epistula fundamenti; Papyrologica Coloniensia 27/2; Paderborn: Schöningh, 2002), 28, l. 3.

26 Adu. Man. 5, 16 a priore lucida sua natura. Cf. Mani's Epistula fundamenti (ed. Stein, Manichaica latina 2), 36, 1. 1.

27 Adu. Man. 14, 2-3 tunc beatus ille pater, qui lucidas naues habet; Adu. Man. 15, 3: plenae sunt lucidae naues; Adu. Man. 15, 11: ascendunt ad lucidas naues. Cf. Mani's Thesaurus (ed. Stein, Manichaica latina 4), 38, 1. 1. 40, l. 18. 40, l. 26.

28 Adu. Man. 14, 10 uirginum lucidarum forma. C. Mani's Thesaurus (ed. Stein, Manichaica latina 4), 40, l. 9 . 
authentic Manichaean doctrine ${ }^{29}$ ). The terms lumen $^{30}$ and especially lux $x^{31}$ are widely attested in the Manichaean citations as well. The sun and the moon play an important role in Manichaean cosmology, as these two celestial bodies are seen as sources of light. The phases of the moon reflect the presence of light particles - souls - in the moon. With regard to the sun, Evodius merely states that the Manichaeans "bend their knee to it,"32 though its importance in Manichaean doctrine is well documented in Manichaean texts. ${ }^{33}$

The opposite concept, that of darkness (tenebrae), also frequently occurs in Manichaean texts, albeit to a lesser extent than the terms regarding light. ${ }^{34}$ Manichaean texts describe darkness in hostile terms. Darkness is the opposite of light, and caused the present cosmic conflict. The terminology of fire also occurs in the Manichaean texts. Perhaps somewhat surprisingly (as it could be seen as a source of light), fire is described exclusively in negative terms and as pertaining to the kingdom of darkness, ${ }^{35}$ perhaps due to its destructive properties. Similarly, when Evodius rephrases the Manichaean myth, he uses the

29 Adu. Man. 49, 33-34 ad lucidum illum tectorium. Augustine also refers to this term in his public debate with Felix, who did not object to this image. Augustine, c. Fel. 2, 7 (CSEL 25/2, 835) facturum eum dicitis uelut tectorium genti tenebrarum. In his entry on the Manichaeans in De haeresibus, Augustine uses a similar expression. Augustine, haer. 46, 19 (CCL 46 263-358, 319) Cui globo affirmant accessurum semper et adhaesurum quasi coopertorium atque tectorium.

30 Adu. Man. 5,17 lumini sancto. Cf. Mani's Epistula fundamenti (ed. Stein, Manichaica latina 2), 36 , l. 2.

31 Adu.Man. 5, 24 libertate sanctae lucis alienarentur; Adu. Man. 7, 1-2 lucis autem subsiciuam partem; Adu. Man. 11, 4-5 lucis uero beatissimae pater; Adu. Man. 11, 8 quies lucis incolis pararetur. These citations are all from Mani's Epistula fundamenti. See Stein, Manichaica latina 2, 38, 1. 8-9; 40, 1. 1; 28, 1. 1; 28, 1. 4 .

32 Adu. Man. 24, 10 solem istum, cui genu flectunt.

33 In a long citation from Mani's Thesaurus, found both in Adu. Man. (14, 2-16, 15) and in Augustine's nat. bon. (CSEL 25/2, 881-884), the term lucidae naues is used. Stein, in his commentary on this fragment, notes that the lucidae naues refer to the sun and the moon. The sun is also called clarissima nauis in the same citation. The light in these celestial bodies reflects the presence of light-particles or souls contained within them. The phases of the moon represent the function of the moon in Manichaean salvation. The moon collects souls which become free from their ties with evil matter (waxing of the moon) and delivers the souls to their befitting positions in heaven (waning of the moon). See Stein, Manichaica latina 4, 38-43 and 107-138. Evodius himself does not identify the lucidae naues with the sun and the moon.

34 Adu. Man. 5, 27 relictae in eodem tenebrarum globo; Adu. Man. 11, 5-6 labem magnam ac uastitatem, quae ex tenebris surgeret; Adu. Man. 11, 7-8 quo superet simul ac destruat stirpem tenebrarum; Adu. Man. 13, 4-5 hodie enim diuina quam commemorat substantia subiacet genti tenebrarum ut lutum figulo.

35 Adu. Man. 5, 18 igneo spiritui obsecutae sunt; Adu. Man. 16, 5 quaeque ignem habeant naturam. Another fragment of Mani's Ep. fund. describes fire as an element of darkness. See 
verb accendo in conjunction with concupiscentia and libido, ${ }^{36}$ which affirms the Manichaeans' notional link between fire and sinfulness.

The first chapter of Adu. Man., the introduction of the anti-Manichaean treatise, is a confession of faith. There, Evodius describes God in terms with which Manichaeans could agree. The testimony of 1 Tim 6:16, in particular, is aptly chosen, considering its occurrence in several Latin Manichaean confessions of faith. ${ }^{37}$ In the opening chapter of Adu. Man., God is associated with light on two occasions: Once in the Pauline citation of 1 Tim, and once in a very clear description: "He is the true light." 38 By making use of the central image of light, Evodius wants to convey the message that Catholic Christians teach the truth about God and the light. Before the author introduces the first Manichaean doctrine, he already establishes that light and its associated terms (God, revelation, truth, life) pertain to the Catholic Church and not to Manichaeism. Evodius' selection of attributes is aptly adjusted to the polemical intent of $A d u$. Man. He makes use of terminology which also features in the Manichaean confessions of faith, and not only describes God as all-powerful but also as good. ${ }^{39}$ He reinforces this notion immediately following the confessional introduction to the treatise.

Stein, Manichaica latina 2, 26 rursum regio ignea et corruptibilis cum suis ducibus et nationibus.

$3^{6}$ Adu. Man. 17, 9-10 et spurcissimam concupiscentiam confudit, inuicem accendant; Adu. Man. 47, 14 daemonum libidinem accenderet.

37 Namely in Aug. c. Fort. 3 (CSEL 25/1, 85) [Fortunatus dixit:] Et nostra professio ipsa est, quod incorruptibilis sit deus, quod lucidus, quod inadibilis, intenibilis, inpassibilis, aeternam lucem et propriam habitet: "[Fortunatus said:] And this is our profession: God is incorruptible, bright, unable to be approached, unable to be held, unable to suffer; he dwells in an eternal light of his own"; (trans. Teske, The Manichaean Debate, 146); and Aug. c. Faust. 20, 2 (CSEL 25/1, 536) [Faustus dixit:] Igitur nos patris quidem dei omnipotentis et Christifilii eius et spiritus sancti unum idemque sub triplici appellatione colimus numen; sed patrem quidem ipsum lucem incolere credimus summam ac principalem, quam Paulus alias inaccessibilem uocat: "[Faustus said:] We worship, then, the divinity of God the almighty Father and of Christ his Son and of the Holy Spirit, one and the same God under their three names. But we believe that the Father himself inhabits the highest and principal light, which Paul elsewhere calls inaccessible" (trans. R. Teske, Answer to Faustus, a Manichaean [WSA I/20; New York: New City Press, 2007], 262 [emphasis mine].

38 Adu. Man. 1, 3 ipse lumen uerum.

39 Compare such a description, for example, with Augustine's argumentation against the Manichaean Fortunatus. In the debate between Augustine and Fortunatus, it appears that Augustine primarily defines God as powerful, whereas Fortunatus emphasizes God's goodness, prescience, and wisdom. See Jason David BeDuhn, "Did Augustine Win His Debate with Fortunatus?" in 'In Search of Truth:' Augustine, Manichaeism and other Gnosticism (ed.J.A. van den Berg et al.; Nag Hammadi and Manichaean Studies 74; Leiden and Boston: Brill, 2011), 463-479, 472. 
The actual refutation of the Manichaeans begins with the words huic Manichaeum aduersarium esse dicit: "In opposition to Him, Mani posits an adversary." ${ }^{40}$ In his phrasing, Evodius creates a sharp contrast between huic-God, as we correctly believe, the true light - on the one hand, and ManichaeusMani and his false teachings - on the other hand. The implication that the Manichaean teachings on light are false and blasphemous is repeated throughout Adu. Man. The author uses the phrase de lumine lumen (or lux de lumine) in two passages, to ridicule the Manichaeans' views on God and light. ${ }^{41}$ Elsewhere, he criticises the dualistic anthropology of the Manichaeans. If man consists of light and darkness, either the light sins, which would mean that God sins (a notion that is entirely blasphemous) ${ }^{42}$ or alternatively, darkness sins. The second possibility could have two consequences. If only darkness (our body) sins, then our souls are free from guilt. ${ }^{43}$ Alternatively, if only darkness sins, Christ will save the race of darkness. ${ }^{44}$ Needless to say, Evodius considers both alternatives impious, and he subsequently introduces the correct Catholic view on anthropology and sin with the words: "But what does the truth claim?" (Sed quid ueritas clamat?). ${ }^{45}$

Evodius subtly corrects the Manichaean conception of fire. Like the Manichaeans, he underlines the destructive force of fire. He cites biblical passages that link the concept of fire to hell and destruction. ${ }^{46}$ However, he makes clear that fire does not entail blind destruction, but rather functions as a just punishment for sinners. When Manichaeans criticise Deuteronomy's description of God as a "consuming fire" (ignis edax; Deut 4:24), Evodius counters

\footnotetext{
$40 \quad$ Adu.Man. 2, 1.

41 Adu.Man. 12, 8; Adu. Man. 43, 11.

42 Adu.Man. 43, 7-8 Sed si pars lucis peccat, deus peccat, quod nefas est dicere: "But, if the part of light sins, God sins, which is a wicked thing to say!"

43 Adu. Man. 43, 1-2 Si ... et non peccat nisi gens tenebrarum, restat, ut ab omni peccato pars lucis immunis inueniatur: "... and if no one sins except the race of darkness, the result is that the part of light will be found void of any sin".

44 Adu. Man. 43,8-10 Si autem pars tenebrarum peccat, ipsa uocatur ad regnum per eum, qui dixit:non ueni uocare iustos sed peccatores, quia non est opus sanis medicus, sed male habentibus: "If, then, the part of darkness sins, this part will be summoned to the kingdom by him who said: I have come not to call the righteous but sinners, for those who are well have no need of a physician, but those who are sick do" [Matt 9:13-12].

45 Adu.Man. 44, 8.

46 Adu. Man. 7, 4-6 cum ipsum dominum nostrum Iesum Christum nolitis intellegere dicentem ignem praeparatum esse peccatoribus et diabolo et angelis eius [Matt 25:41]; Adu. Man. 37, 24-25 nam quod ait: qui dixerit fratri suo fatue, reus erit gehennae ignis [Matt 5:22]; Adu. Man. 37, 4 et ignis edax [Deut 4:24]; Adu. Man. 37, 14 et ignem ueni mittere in mundum [Luke 12:49].
} 
this criticism by saying that Jesus, too, threatened with fire (ignem ueni mittere in mundum; Luke 12:49). This latter example makes it clear that fire is not an utterly negative force, as the Manichaeans believe, and that fire, although destructive, nonetheless has a purpose within God's providential order. Neither the Manichaeans nor Evodius interpret fire as a source of light.

As mentioned earlier, Evodius is mostly concerned with the refutation of the Manichaeans on a doctrinal level. Thus, knowledge is a central topic in Adu. Man. Evodius uses the language of light, or perhaps more specifically, of clarifying (declaro, innotesco, manifesto), to describe the revelatory character of knowledge. He understands knowledge as revelatory, with both a passive component (knowledge is revealed, and one needs to be receptive to revealed knowledge) and an active component (one is required to have a right mindset or to seek out the truth actively). For example, in Adu. Man. 39, the author defends the unity of the Old Testament and the New Testament, and cites several Old Testament miracles, which anticipated those of the New Testament. These examples become known to people (innotescunt: passive component) who are industrious and piously seek for them (diligentibus et pie quaerentibus: active component). ${ }^{47}$ The verb manifesto is used in a similar way in the opening chapter of Adu. Man.: The correct teachings reveal themselves (manifestatur: passive component) to those who are humble (humilibus: active component) and piously seek them (pie quaerentibus: active component).$^{48}$ If Evodius describes knowledge and teachings in terms of revelation and openness, he similarly accuses the Manichaeans of blindness (caecitas) and bad intent (malitia). ${ }^{49}$ The terminology of darkness - in particular, the repeated accusation that the Manichaeans are blind - situates the Manichaeans within, or close to, the realm of darkness. ${ }^{50}$ The Manichaeans would surely have been sensitive to such a metaphor.

\footnotetext{
47 Adu.Man. 39, 4-5 et alia multa quae diligentibus et pie quaerentibus ad aedificandam fidem innotescunt.

48 Adu. Man. 1, 7-8 sicut in utroque testamento humilibus et pie quaerentibus manifestatur.

49 The association of Manichaeism and blindness occurs 11 times in total in Adu. Man. The accusation of malitia occurs twice: Adu. Man. 38, 14-15 Multum apparet inperitia uestra uel potius malitia; Adu. Man. 39, 11-12 Numquid et hoc poterit dicere malitia uestra ...?

$5^{\circ} \quad$ See in particular Adu. Man. 21, 3-4 O utinam uidere possint quod facile uiderent, nisi per nebulas contentionis excaecarentur: "Oh, if only you could see-what you would easily see, were you not blinded by the thick clouds of strife".
} 


\subsection{Mani and the Manichaeans}

\subsubsection{Mani's Distinct Role in Adu. Man.}

Evodius makes a distinction between Mani, on the one hand, and the Manichaeans, on the other hand. The same word Manichaeus can refer to Mani (singular) or to the Manichaeans (plural). The use of Manichaeus in the singular to refer to "a (hypothetical or stereotypical) Manichaean" cannot be found in Adu. Man. ${ }^{51}$ The name Manichaeus occurs 34 times in the treatise: 27 times in the singular and 7 times in plural. With the addition of references to the Manichaeans in the second person plural (the addressees of the treatise) and the third person plural, Evodius more frequently describes the Manichaeans than Mani himself.

Evodius describes Mani as blasphemous, erring, lying, bold, and disgraceful. ${ }^{52}$ Most of these characteristics also apply to the Manichaeans. However, Mani does fulfil a more particular role as the author of the Manichaean texts. The contents of these texts are ascribed specifically to Mani himself, ${ }^{53}$ and the same is the case for some of the Manichaean doctrines addressed in the treatise. ${ }^{54}$ When summarizing the Manichaean myth, the author often employs phrases such as "Mani's god," whereas the phrase "your (plural) god" only occurs once. ${ }^{55}$ The distinction between Mani and the Manichaeans has pragmatic argumentative consequences since it allows the author to characterize the Manichaeans differently to how he describes Mani.

$5^{1}$ Compare, for example, with Quodvultdeus' sermon Adu. v haer. There, the term Manichaeus likely refers to "a Manichaean," and not to Mani. This use of Manichaeus would be analogous to his use of Arianus or Sabellianus instead of Arius or Sabellius. See Quodvultdeus, Adu. vhaer. 6 (ccsL 6o, 279) Vellem adhuc persequi Manichaeum, sed infestum patior Arianum.

$5^{2}$ His characterization of the Manichaeans corresponds to Latin anti-Manichaean literature in general and to Augustine's anti-Manichaean language in particular. In anti-Manichaean polemical language, the Manichaeans are most frequently refuted as immoral. See Ilona Opelt, Die Polemik in der christlichen lateinischen Literaturvon Tertullian bis Augustin (Bibliothek der klassischen Altertumswissenchaften, N. F., 2. Reihe, 63; Heidelberg: Winter, 1980), 143-146.

53 See, for example, Adu. Man. 14, 1-2 Qualis interea turpitudo, quam in eodem Thesauro suo inter cetera turpia in septimo libro scribit sic dicens: "Meanwhile, he writes of such a disgrace in the seventh book of that same Treasure among other disgraceful things when he says the following".

54 See, for example, Adu. Man. 24, 3-4 qui se mira superbia assumptum a gemino suo, hoc est, a Spiritu sancto esse gloriatur: "He, in an astonishing display of pride, boasted he was adopted by his twin (this is, the Holy Spirit)". 


\subsubsection{The Manichaeans}

Evodius makes use of a wide range of negative terms to depict the Manichaeans. Similarly to their founder, they err, they are blasphemous, vain, bold, miserable, mad, sinful, and contentious. The author further fleshes out some of these characteristics. One important trait of the Manichaeans is their boldness. Much more than Mani himself, the Manichaeans actively criticize Catholic doctrines. They "bark" (latrant) against Catholic teachings, ${ }^{56}$ and are more eager to accuse passages of (Old Testament) scripture rather than understand them. ${ }^{57}$ This trait is accentuated by their ignorance. The most frequently levelled accusation against the Manichaeans is their blindness. As was described above, this blindness signifies a lack of insight or knowledge. Because the Manichaeans do not know better, and refuse to know better, they are inclined to criticize the Christian teachings which the author describes as common sense. ${ }^{58}$ On one occasion, Evodius explicitly reflects on a cause of the Manichaeans' blindness: "Oh, if only they could see what they would easily see, were they not blinded by the thick clouds of strife." ${ }^{99}$ The Manichaeans' blindness results from their bad intentions. The centrality of the trait of blindness underlines Evodius' concern with the refutation of Manichaeism on a doctrinal level. Blindness entails that one is not receptive to self-revelatory truth.

In some instances, Evodius shows openness and genuine concern towards the Manichaeans. In this regard, the central metaphor of blindness can have an additional implication for the argumentation of Adu. Man. Blindness is a (medical) condition. In some sense, the Manichaeans are victims of this condition. They are not able to notice their own blindness. ${ }^{60}$ Here the distinction between Mani and the Manichaeans becomes very pertinent. Mani is the founder of the false religion. Mani is the author of the scandalous Manichaean myth. The Manichaeans are being deceived by Mani. ${ }^{61}$ The Manichaeans are blind when they believe Mani. ${ }^{62}$ By focussing on a doctrinal refutation of Manichaeism,

56 Adu. Man. 9, 8-9 Aduersus haec solita caecitate Manichaei latrant.

57 Adu. Man. 38, 3 ut temere accusetis quod non intelligitis.

$5^{8}$ See Adu.Man. 32, 2-3 omnis sana fides Christum pro nobis passum confitetur: "Every sound faith confesses that Christ suffered for us"; Adu. Man. 44, 8 Sed quid ueritas clamat?: "Yet, what does the truth say?".

59 Adu.Man. 21, 3-4O utinam uidere possint quod facile uiderent, nisi per nebulas contentionis excaecarentur.

6o Adu.Man. 9, 11 et non uident caecitatem suam: "and they do not see their own blindness".

61 Adu. Man. 42, 1 Vos ergo homines, qui ista impietate Manichaei estis decepti, fugite: "Therefore, you, people who are deceived by Mani's notorious impiety, run".

62 Adu. Man. 17, 14-16 Deus magne, subueni animis ista turpia credentibus, ista nefanda sectantibus. Quis haec non exhorreat, rogo uos? Quis tam caecus est, ut ista credat, rogo uos?: 
Evodius invites the Manichaeans to reject Mani's teachings. Elsewhere the author cites Jn 9:39: "I came so that those who do not see may see, and those who do see may become blind." 63 Although the author does not make this connection himself, it is possible to associate the Manichaeans' blindness with the qui non uident in the Johannine citation.

Evodius repeats the invitation to the Manichaeans to become true Christians in the last chapters of his treatise. The possibility that Manichaeans could have good intentions serves the argumentative purpose of the treatise. He does consider the Manichaeans' blindness and impiety to be sinful, and established that everyone was personally responsible for his/her own sins. ${ }^{64}$ By making an appeal to the Manichaeans' conscience, however, he forces his addressees to confess their position openly. The author has already sufficiently argued that if they choose to believe Mani's myth they would remain irrational, sinful, evil, and subject to punishment by God.

If, on the other hand, the Manichaeans were to respond correctly to the appeal to their conscience, they would acknowledge their sinfulness as a first step towards liberation. A clear example is the opening sentence of the treatise's penultimate chapter: "If, however, the things we say are true, look back then, see the kind of death you have won for yourselves." ${ }^{5}$ The author situates the correct Christian teachings among the first person plural (quae dicimus): "what we [true Christians] believe." The Manichaeans' present unbelief, on the other hand, is very expressively described as "death." The terms respicite and uidete, both signify "seeing”, are in stark contrast to the Manichaeans' earlier condition of blindness. Once the Manichaeans realise their current views are wrong, they should renounce Mani's error ${ }^{66}$ and convert to Catholic Christian-

"Great God, aid these souls, which believe such disgraceful teaching, which pursue these illicit doctrines. Who would not tremble before these words, I ask you? Who is blind to such an extent that he would believe those words, I ask you?"

63 Cited in Adu. Man. 37, 14-15 ueni ut qui non uident uideant, et qui uident caeci fiant. Although Evodius does not refer to any other biblical passage on blindness, the term very frequently returns in the Gospels, for example in Mk 8:18: "Do you have eyes, and fail to see?" [trans. NRSv].

64 Adu.Man. 10, 4-7 Sed quid uerum est nisi et dominum dare praecepta et animas liberae esse uoluntatis et malum naturam non esse, sed esse auersionem a dei praeceptis, et esse iustum iudicium dei quo damnet peccantes?: "But what else is true, except that and the Lord gives precepts, and the souls possess a free will? And is it not true that evil is not a nature, but rather a turning aside from God's precepts, and that it is through His righteous judgement that God punishes sinners?"

65 Adu. Man. 48,1-2 Si autem uera sunt, quae dicimus, tandem respicite, tandem uidete, in qua estis morte constituti.

66 Adu. Man. 49, 8 hoc dicite Manichaeo et renuntiate eius errori. 
ity. In order to reinforce his message, the author attempts to dissociate the Manichaeans from Mani.

\subsection{Creating a Distance between Mani and the Manichaeans}

Evodius deliberately creates a distinction between Mani and the Manichaeans. Often, the author singles out Mani in his polemical discourse. When he does so, he characterises Mani as the errant teacher of the Manichaeans. ${ }^{67} \mathrm{He}$ uses the distinction between Mani and the Manichaeans as an argumentative tool in order to persuade the Manichaeans. This actively allows him to identify the fault of the Manichaeans as something that, to an extent, can be situated outside the Manichaeans themselves. The fault lies primarily with the myth and doctrines of Mani. Surely, the Manichaeans are expected to reject their Manichaean identity. Evodius makes this very clear in the penultimate chapter of Adu. Man:: "Confess this, and you will be Manichaeans no more."68

Throughout the treatise, Evodius attempts to pull the Manichaeans closer to him and further away from Mani. In the aforementioned example (hoc confitemini et non iam eritis Manichaei), he used the demonstrative pronoun hoc to illustrate how the correct teachings - which the Manichaeans should confess-are situated close to the party of the speaker. The Manichaeans only need to accept Catholic doctrine-continuously described as truth, common sense, or healthy belief - in order to cease being Manichaeans. The placement of the essential term Manichaei at the end of the sentence serves to reinforce his appeal. Furthermore, the very next sentence starts with Manichaeus (singular), ${ }^{69}$ which creates a sharp contrast between the Manichaeans, summoned to become Catholic Christians, and Mani, the false teacher.

Particularly near the end of his treatise, Evodius makes use of the rhetorical procedure of creating distance between Mani and the Manichaeans. Chapter 46 begins with an exhortation towards the Manichaeans, who are addressed directly. ${ }^{70}$ The author then presents two alternatives. Chapter 46 first depicts the one true God, "which the Catholic faith preaches." ${ }^{71}$ It should be noted here that the author connects the concept of catholica to fides ("faith, belief"),

67 E.g. Adu. Man. 17, 1-2 Quis non rideat uel potius doleat et detestetur istum hominem tam horrenda et exsecrabilia de diuina substantia dicentem?: "Who would not laugh at someone, or rather feel sorrow and hate towards that man who says such horrible and accursed things about the divine substance?".

68 Adu. Man. 48, 15-16 hoc confitemini et non iam eritis Manichaei.

69 Adu. Man. 49, 1 Manichaeus enim duas dicit esse naturas.

70 Adu. Man. 46, 1 Iudicate tandem aut eligite, Manichaei, quem sequi uultis.

71 Adu. Man. 46, 16 quem praedicat catholica fides. 
and not, in the first place, to the catholica ecclesia. ${ }^{72}$ Afterwards, and in contrast to the Catholic views, chapter 47 offers a description of "the god Mani preaches." 73 Here, too, the author creates a contrast between Manichaeus and the addressees, the Manichaeans. He specifically makes an appeal to their conscience. ${ }^{74}$ The Manichaeans have the moral and intellectual capacity to realise Mani's falsehood and to react accordingly.

The closing words of Adu. Man. aptly summarize Evodius' general attitude towards the Manichaeans. These closing words have strong rhetorical qualities:

Let go of such grave and horrible blasphemy. Do not let such iniquity reach your ears any longer. Stop getting involved in such a deadly occupation. Flee from Mani, and aim your utmost longing to the safe teachings of the Catholic truth. ${ }^{75}$

These phrases are preceded by a fictitious soliloquy. Evodius asks the Manichaeans, in the form of a soliloquy, to consider the consequences of the Manichaean myth. From his point of view, Mani's god cannot offer solace or salvation to the Manichaeans, for he is not able to overcome evil. The Manichaean system cannot guarantee the prevention of a new invasion of evil. This prompts the author to finish the soliloquy abruptly and come to his final exhortation. These final sentences are well-structured. His conclusion contains four sentences, the verbs of which are all in a volitive mood. The first sentence contains a subjunctive in the third person (absit). The following two sentences contain the imperatives nolite (second person plural). The repetition of the imperative emphasizes the urgency of Evodius' commands. The last sentence also contains two imperatives in the second person plural, namely fugite and conuolate. Formally, a distinction can thus be made between the volitive expressions in the third person (absit) and in the second person (nolite, nolite, fugite, conuolate). There is also a clear effect of crescendo in this passage. The first phrase (absit) contains no reference to the second person, as the author merely describes the

72 This term only occurs in the preceding chapter 45, and even there the Ecclesia catholica is primarily described in the terminology of teaching and truth. See Adu. Man. 45, 4-5 ad sinum matris Ecclesiae catholicae, quae sola ueritatem docet: "to the lap of the mother, which is the Catholic Church. She alone teaches the truth".

73 Adu. Man. 47, 14-15 quem praedicat Manichaeus.

74 Adu. Man. 47, 15 aut certe, si potest, neget conscientia uestra: "But certainly, if it is possible, may your conscience oppose to this".

75 Adu. Man. 49, 36-39 Absit tam grauis et tam abominanda blasphemia. Nolite istam iniquitatem ad aures uestras admittere. Nolite tali negotio mortifero uos implicare. Fugite Manichaeum et ad ueritatis catholicae ubera toto desiderio conuolate. 
Manichaean myth as a "grave and horrible blasphemy." In the second series of commands, the author repeats the verb nolite, and the addressees gradually become more involved. In the first command, the Manichaean teachings are qualified as iniquity, and situated near the second person by means of the demonstrative pronoun istam (perhaps with a negative connotation, such as: "there can be no doubt that these blasphemous teachings circulate among you, Manichaeans"). The iniquity, which Evodius mentions, pertains to an attribute of the Manichaeans, namely, their ears (ad aures uestras). In the second command, the "iniquity" has become a "deadly occupation." This threat does not concern an attribute of the Manichaeans, but rather the core identity of his addressees. The change of terminology from admittere ad aures uestras ("to allow something to reach your ears") to uos implicare ("to involve yourself") is significant. The final two commands are included in one sentence. The first of these is the shortest command of the series, but perhaps the most rhetorically evocative: fugite Manichaeum. The form reflects the content. In the syntactical construction, the Manichaeans (second person plural) have already liberated themselves from Mani (third person singular). The very concise phrasing of the penultimate command results in a greater emphasis on the final, more elaborate, commandment. The imperative conuolate is the final word of the treatise. This final command is distinct from all previous four volitive constructions on two levels. The preceding four verbs were all placed at the beginning of their respective sentences. The position of conuolate at the end of the sentence creates an effect of chiasmus. Additionly, the four earlier commandments were all formulated negatively, as a prohibition ( fugite also expresses what not to do), whereas conuolate is the only positive command. The author realizes a final, rhetorically-effective contrast by setting Mani (Manichaeum) against the truth of the Catholic Church. The metaphor of ubera evokes the image of a nurturing mother, and probably alludes to Paul's metaphor of milk in his First Epistle to the Corinthians, as well. ${ }^{76}$ The commands Evodius gives to the Manichaeans cover only the initial steps of the Manichaeans' hoped-for conversion. First they need to realize their error and distance themselves from Mani. Afterwards, they can be introduced to the baby food of the Catholic truth.

76 1Cor 3:2: "I fed you with milk, not solid food, for you were not ready for solid food"; trans. NRSV. 


\section{$4 \quad$ Conclusion}

Aduersus Manichaeos is an important testimony on the confrontation between Catholic and Manichaean Christians. It represents the views of the leader of one of the two religious communities involved in polemical debates. At the beginning of the third decade of the fifth century, Evodius wrote a treatise in which he wanted to convert the Manichaeans to Catholic Christianity. In several instances, Evodius presents his opponents' arguments in the form of a dialogue situated in the historical past. ${ }^{77}$ While one should not overlook the possibility that these sections could be fictitious dialogues, it may be true that Evodius could have already discussed some of the addressed topics prior to this in oral disputes with Manichaeans in Uzalis.

Evodius attempts to persuade his Manichaean audience by making use of the argumentative techniques of appropriation and dissociation or distancing. Thus, he chose a specific approach in his persuasion of the Manichaeans. He attempted to convince them almost exclusively through logical and biblicalhermeneutical arguments. He interacted with Manichaean terminology and appropriated one of the Manichaeans' central images, that of light, in his defence of Catholic Christianity. Light is a universal metaphor for good, and Evodius wants to monopolize this term by situating the true knowledge of light within the Catholic party. In doing this, he establishes the notion that whatever the Manichaeans believe about light - a fundamental element in their cosmology - is probably not true.

In contrast, Evodius subtly, mostly by means of the metaphor of blindness, characterizes the Manichaeans, the religious "other," in terms pertaining to darkness. The accusation of blindness is significant on multiple levels. First, as was previously mentioned, this accusation situates the Manichaeans in the realm of darkness, in stark contrast to their claim to "light." Second, the accusation refers to the theme of knowledge. The author wants to achieve conversion of the Manichaeans on an intellectual and confessional level. Because knowledge is revelatory and reveals itself to whomsoever is receptive to it, the Manichaeans are accused of having wrong intentions, and are implored to be more open towards the author's Catholic position. Should the Manichaeans strive for illumination, they are encouraged to abandon Mani's false teachings. Third, blindness is a condition from which the Manichaeans suffer, and the author wants to cure the Manichaeans of this. 
Evodius attempts to realise this cure, the conversion to Catholicism, by dissociating the Manichaeans and Mani. He describes Mani as a false teacher. $\mathrm{He}$ states that the Manichaeans are being deceived by Mani and employs rhetorical strategies to create a distance between Mani and the Manichaeans. Overall, the author is not concerned with the Manichaean church, with Manichaean ritual practices, or with the practical moral life of Manichaeans. The treatise is almost exclusively focussed on doctrine and scriptural hermeneutics. The envisaged conversion consists of a basic rejection of Manichaean teaching and an openness towards the Catholic teaching. In other words, Evodius could seem to invite the Manichaeans to the Catholic catechumenate.

Because of its doctrinal focus, the treatise can also be seen as a pragmatic compendium of anti-Manichaean argumentation, which could have helped prepare Christian communities in North Africa and in Medieval Europe against the Manichaeans or, more broadly, against dualistic interpretations of Christianity. In some cases, the author seems to address a Catholic audience. However, the second person plural is mostly used to address Manichaeans directly. At the very least, the direct appeal towards the Manichaeans functions as a rhetorical strategy, and one which could certainly convince a favourable audience.

\section{Bibliography}

Bauer, Johannes B. Sancti Aureli Augustini opera De moribus ecclesiae catholicae et de moribus Manichaeorum. cSEL 9o. Vienna: Hölder-Pichler-Tempsky, 1992.

BeDuhn, Jason David. "Did Augustine Win His Debate with Fortunatus?" Pages 463-479 in 'In Search of Truth:' Augustine, Manichaeism and other Gnosticism. Edited by J.A. van den Berg et al. Nag Hammadi and Manichaean Studies 74. Leiden and Boston: Brill, 2011.

Boersma, Gerald P. “Augustine's Immanent Critique of Stoicism." Scottish Journal of Theology 70 (2017): 184-197.

Braun, René. Opera Quodvultdeo Carthaginiensi episcopo tributa. CCsL 6o. Turnhout: Brepols, 1976.

Decret, François. “Le traité d'Evodius contre les Manichéens: un compendium à l' usage du parfait controversiste." Augustinianum 31 (1991): 387-409.

Decret, François. "Exégèse et polémique chez Evodius d' Uzalis." Pages 383-389 in L'Esegesi dei padri latini: dalle origini a Gregorio Magno. Studia Ephemeridis Augustinianum 68, vol. 1: Parte Generale-Oriente, Africa. Rome: Institutum Patristicum Augustinianum, 2000.

Drever, Matthew. "Redeeming Creation: Creatio ex nihilo and the Imago Dei in Augustine." International Journal of Systematic Theology 15 (2013): 135-153. 
Dubois, Jean-Daniel. "Le manichéisme: À la lumière des documents nouveaux." Pages 42-84 in Contre Fauste le manichéen: Livres I-XII. Edited by Martine Dulaey. Bibliothèque Augustinienne 18/A. Paris: Institut d'études augustiniennes, 2018.

Duval, Yves-Marie. "Note sur la lettre d'Evodius à l'abbé Valentin d'Hadrumète (CPL 389)." Revue des Études Augustiniennes 49 (2003): 123-130.

Gardner, Iain and Samuel Lieu. Manichaean Texts from the Roman Empire. Cambridge: Cambridge University Press, 2004.

Kotzé, Annemaré. "Protreptic, Paraenetic and Augustine's Confessions." Pages 3-23 in 'In Search of Truth:' Augustine, Manichaeism and other Gnosticism. Edited by J.A. van den Berg et al. Nag Hammadi and Manichaean Studies 74. Leiden and Boston: Brill, 2011.

Oort, Johannes van. "Manichaean Christians in Augustine's Life and Works." Church History and Religious Culture 9o (2010): 505-546.

Opelt, Ilona. Die Polemik in der christlichen lateinischen Literatur von Tertullian bis Augustin. Bibliothek der klassischen Altertumswissenchaften, N. F., 2. Reihe 63. Heidelberg: Winter, 1980.

Stein, Markus. Manichaica latina 2: Manichaei epistula fundamenti. Papyrologica Coloniensia 27/2. Paderborn: Schöningh, 2002.

Stein, Markus. Manichaica latina 4: Manichaei Thesaurus. Papyrologica Coloniensia 27/4. Paderborn: Schöningh, 2016.

Tardieu, Michel. Le manichéisme. Que sais-je? 1940. Paris: PUF, 1981.

Teske, Roland. The Manichaean Debate. Works of Saint Augustine I/19. New York: New City Press, 2006.

Teske, Roland. Answer to Faustus, a Manichaean. Works of Saint Augustine I/2o. New York: New City Press, 2007.

Vander Plaetse, Roel and Clemens Beukers. "De haeresibus." Pages $263-358$ in De fide rerum inuisibilium, enchiridion ad Laurentium de fide et spe et caritate, de catechizandis rudibus, sermo ad catechumenos de symbolo, sermo de disciplina christiana, de utilitate ieiunii, sermo de excidio urbis Romae, de haeresibus. Edited by M.P.J. van den Hout et al. cCsL 46. Turnhout: Brepols, 1969.

Vanspauwen, Aäron. “'Contra Domini uel Apostoli auctoritatem': la autoridad de Pablo en el tratado polémico 'De fide contra Manichæos' de Evodio de Uzala.” Augustinus 61 (2016): 395-411.

Vanspauwen, Aäron. "The anti-Manichaean Treatise De fide contra Manichaeos, Attributed to Evodius of Uzalis: Critical Edition and Translation." Sacris Erudiri 57 (2018): 7-116.

Vanspauwen, Aäron. "In Defence of Faith, Against the Manichaeans: Critical Edition and Historical, Literary and Theological Study of the Treatise Aduersus Manichaeos, Attributed to Evodius of Uzalis." Ph.D. diss., Ku Leuven, 2019.

Zycha, Josephus, ed. S. Aureli Augustini de utilitate credendi, de duabus animabus, con- 
tra Fortunatum, contra Adimantum, contra epistulam fundamenti, contra Faustum. CSEL 25/1. Prague: Temspky, 1891.

Zycha, Josephus, ed. Sancti Aureli Augustini contra Felicem, de natura boni, epistula Secundini, contra Secundinum, accedunt Euodii de fide contra Manichaeos et commonitorium Augustini quod fertur. CSEL 25/2. Prague: Temspky, 1892. 